DOI: 10.24234/wisdom.v17i1.428

Oleg NAUMENKO,

Utkir SAPAEV,

Alla SKATERSHCHIKOVA,

Rauf BEKBAEV

\title{
“ARTIFICIAL INTELLIGENCE": PHILOSOPHICAL ASPECTS OF UNDERSTANDING
}

\begin{abstract}
The problem of "artificial intelligence" is becoming more and more relevant today. This topic is also of great interest to philosophers. This article considers primarily a retrospective analysis of the study of the possibilities of artificially created mechanisms that first perform primitive actions and then more complex ones, including thought processes. Then the article provides a particular philosophical analysis of the concept of "artificial intelligence", its capabilities and potential danger.
\end{abstract}

Keywords: artificial intelligence, philosophical aspects, strong and weak artificial intelligence, friendly artificial intelligence robotics, history of robotics.

Introduction

The intensive development of modern information and digital technologies has a substantial impact on all spheres of society, which was especially evident during the global pandemic not only in the field of education but also in business and in the activities of government agencies. The development of artificial intelligence also does not stand aside. Modern researchers emphasize that the large-scale development of the nanoindustry spheres replaces the essence of man as a kind of biosocial being living simultaneously in different worlds: not only in the world of physiccal and biological processes but also in the world of culture; not only in the natural world but also in the artificial world (Lektorsky, 2015, pp. 315). It is interesting that the German anthropologist Arnold Gehlen (1988), calling a person “an insufficient being", drew attention to the fact that individuals create an artificial environment - culture. Now, a person who leads his life in the artificial environment created by him creates artificial intelligence, the further improvement of which presents us with a whole palette of a wide variety of problems that require their full understanding.

The concept of "artificial intelligence" is firmly included in our life and, in the future, will actively influence all spheres of human life. A large amount of science fiction, research and popular literature is devoted to this concept. Retrospective analysis and research of theoretical content will help introduce the problem of "artificial intelligence" as a complex and ambiguous philosophical phenomenon that can become a decisive factor in the transmutation of human consciousness. 


\section{Old Time Legends Concerning}

Thinking Machines

The very phenomenon of artificial intelligence was gradually developed in individuals' minds because it has historical roots of its origin. So, since antiquity, people have imagined various kinds of creatures created by the gods to perform any functions. These are sentient mechanisms capable of following orders and acting independently. Robot-like creatures guard the divine justice. In ancient China, there is a legend about the iron giant $\mathrm{Chi} \mathrm{Yu}$ (from Chinese - Ugly or Big Joker), who administers justice and wages war with sinners (Yezhov, 2004). On the relief in the U-Lyantsy temple (II century), he is depicted as a half-beast-half-man with the head of a leopard, and the claws of a tiger, a shield over his head, an axe in one hand, a sword in the other, his left foot is placed on a crossbow, in the claws of his right leg, there is an axe. In "Shu Chi" ("Description of the Amazing") by Ren Fang (V century), another version is given: $\mathrm{Chi} \mathrm{Yu}$ has a human body, bull hooves, four eyes and six arms.

The ancient Greek mythological character Daedalus was not only famous for his labyrinth for the Minotaur and flights against his son Icarus, but he also becomes the greatest architect and sculptor of Athens. It was said that the moving bronze sculptures created by his hands were able to roll his eyes, cry, speak and move his limbs. These sculptures were so real that Hercules, seeing the statue of a man in a fighting stance, thought that someone was attacking him and instinctively reacted by destroying him. When he realized that he had destroyed a beautiful statue depicting himself, he was ashamed and asked for forgiveness from Daedalus (Jones, 1985).
The ancient Greek god Hephaestus was a skilled craftsman in creating various kinds of mechanisms, for example, a giant bronze warrior who defended the sacred fire on Olympus (Losev, 1991, pp. 299-300). It is he who is credited with creating two mechanical dogs to guard the palace of Zeus. His other invention is "fire-breathing mechanical bulls", which the Argonauts allegedly used. There are also four mechanical chariot horses, self-propelled "copper" tripods on wheels that brought food and wine to the guests, as well as two "life-size" maids who carried out any orders of Hephaestus. But his most famous "invention" is Pandora. All this he did on the orders of his great father - Zeus. Pandora was created as a punishment for the act of Prometheus (stealing fire). Many gods took part in the creation of Pandora. Being the wife of the brother of Prometheus Epimetheus, with her curiosity, she opened the casket named after her. It was a kind of revenge on humanity.

So, in ancient mythology, we are already faced with concepts similar to artificial intelligence, but at the same time, specific historical examples should be cited. The ancient Greek philosopher, mathematician and mechanic Archytas of Tarentum (428-347 BC) designed the first flying machine - a wooden bird capable of independently moving its wings with steam and traverse to 200 meters (Diogenes Laertius, 1986). The next step was the invention of the ancient Greek mathematician Ctesibius of Alexandria (285-222 BC) in $250 \mathrm{BC}$, ingenious water clock called clepsydras, which became the most accurate timekeepers until the invention of the pendulum in the $17^{\text {th }}$ century by the Dutch physicist Christian Huygens to maintain undamped oscillations (Russo, 2004).

In $213 \mathrm{BC}$, Archimedes developed a manipulator called the "Claw", which was able to 
lift an enemy ship out of the water and turn it over. There is even "eyewitness testimony" that the manipulator existed in reality (The Claw, 1999).

Medieval scientist and inventor Philo of Alexandria for fun invented and created a mechanical girl who delivers drinks and viands during a feast (Shank, 2007). She could not be aware of her actions. They were fully automated. However, the impression was that she was alive, despite the clear sequence and repetition of her movements.

In the Renaissance, Leonardo da Vinci, according to his own drawings, created a robotic knight that was able to sit, stand up, move his arms, legs and head, and also raise the visor. This is the first surviving blueprint of a mechanical creature that modern scientists managed to reproduce (Sweeney, 2007).

Probably one of the most amazing and mysterious inventions of the modern era belongs to the greatest scientist and philosopher, Rene Descartes - "Descartes' doll". Such a soulless name means preserving the memory of his untimely deceased daughter of the great mathematician Francine (Cave \& Dihal, 2019, pp. 74-78).

There is a legend about the great philosopher and mathematician. Rene Descartes was summoned by Queen Christina of Sweden, who wanted to know his views on love, hate, and the soul's passion. He travelled with his young daughter Francine. However, from the moment they sailed from the coast of France, the sailors had never seen her, and, thinking that this was too strange, they decided to find her in the middle of a terrible storm. For a long time, they could not find either a philosopher or a girl. $\mathrm{Cu}-$ rious, the sailors crept into Descartes' chambers. There was no one there, but after leaving the room, they stopped in front of a mysterious box.
As soon as they opened it, they jumped back in horror: inside the box was a doll - a "living doll", as the sailors thought, which moved and behaved exactly like a person. It turned out that Descartes himself constructed the "android" from pieces of metal and a clockwork. It was indeed his child, but not what the sailors expected: Francine was a machine. When the ship's captain was shown a moving miracle, he was shocked and believed that it was some kind of dark magic instrument responsible for the weather that prevented their journey. By order of the captain, Descartes's "daughter" was thrown overboard.

Is this story true? We still do not know the answer. Descartes actually went to Sweden and, as he feared, died there six months later. In fact, he tried to build several automata earlier in his life (one of his commenters reported that Descartes had plans for "a dancing man, a flying pigeon, and a spaniel chasing a pheasant"), and he continued to be interested in mechanical toys. Nevertheless, the events on the ship read like a fable - about the creation of science, which was the victim of a God-fearing crowd, about the menacing, supernatural power of machines, about a rational philosopher who had an almost superstitious attitude to the product of his own mind. He called "this" his daughter - and whether or not the story is made up of facts, it must in a certain sense correspond to some metaphorical purpose: what is the point of telling it.

Descartes did have a daughter, and her name was Francine, but by the time the story happened, Francine had been dead for many years. She was born in 1635 to a maid named Helene Jans, whom Descartes never married. At least for a time, she lived with her father in the Netherlands, and he planned to take her with him to France. However, this was not destined to happen. Francine dies of scarlet fever at the age 
of five. Descartes told one of his friends that her death was the greatest sadness in his life.

From this point of view, Descartes in this story appears not as a reasoning philosopher but as a human being prone to errors, maddened by the death of his child. Unable to mourn her, he constructs a simulacrum of the girl, gives it the power of movement, and names it after her. If death existed, as they will call it in the next century, "the suspension of life", then Descartes, having revived this doll, defied mortality and resurrected his daughter. Perhaps he even symbolically did something for his life. A few years earlier, when Descartes focused his efforts on medicine, he wrote that he could live to be one hundred years old. Francine died shortly thereafter. The making of the doll can be seen as an attempt to counter the terrifying madness of his hopes of prolonging life, and then it seems appropriate that the timeless figure with the clockwork should have been destroyed while travelling to the country where he eventually met his death. This suggests that the sailors may have been right to fear the object not in itself but because of Descartes' strange attachment to it (Wood, 2002).

One of the most controversial from a religious and philosophical point of view is the figure of the Golem - a humanoid creature "above the animal, but below the line" created by the righteous man from clay by means of "effective bondage". The appearance of the Golem is no different from a human. Nevertheless, having no soul, he is deprived of the gift of speech, consideration and passion. The golem is only able to do what the righteous person who created it orders it. Nevertheless, this creature has some qualities that ordinary people do not have, especially important for the prevention and disclosure of slander. The golem possesses superhuman physical strength, does not burn in the fire, does not drown in water, is not susceptible to sword or disease, and, if necessary, can become invisible. Ten cubits above the ground and ten cubits underground for him; there is nothing hidden or impossible to comprehend. He sees spiritual objects in their material form (Averintsev, 2007).

Another fascinating legendary or real invention is the "doll of Jacob Bruce" by the famous Scottish alchemist, mystic in the service of Peter Alekseevich (Peter the Great). The people called her "Yashkina Baba". It was rumoured that at night, they saw the shadow of a female figure in his mansion, which moved rather strangely, given that Bruce lived alone, not counting the servants. According to one version, the mechanical doll lived with its creator in the estate near Moscow, where he went after his retirement. She could move and speak, which at first frightened the local peasants, but then they got used to her. According to another version, the girl was not mechanical but woven from flowers, and flowers were fixed with a pin on her head. The Flower Girl could move, but she could not speak. She was the adoration of many of Bruce's young acquaintances. The disappearance, as well as the appearance of the girl, remains a mystery to this day (Chistyakov, 1871, pp. 167-170).

Since the Middle Ages, the era of "automatons" has been developing - as a rule, these were mechanical automatons that were actuated by a spring or a weight that lowered on blocks under the action of gravity, like in a clock. It is clear that these products - figurines of people and animals that can move - were created by watchmakers who want to demonstrate their talent.

One of the most famous inventions by the watchmaker Pierre-Jacques Droz was The Writing Boy (1774), which was a five-year-old-sized doll sitting at a table. The automaton's body was 
made of wood, the head was made of porcelain, and it took the watchmaker 20 months to make. The clockwork boy traced a small set of phrases with a quill pen on a blank sheet of paper, blotted the paperweight with ink, looked thoughtfully at what he had written, and then threw away the sheet and began to write again (The Amazing Story of Jaquet Droz, n.d.).

The character of Mary Shelley's "Frankenstein, or Modern Prometheus" (1818) is widely known. The character appears to be the insane physician-inventor Victor Frankenstein, determined to learn how to revive dead matter. One of the many experiments was crowned with the same "success". The result was a nameless monster - animate inanimate matter. The exact process of Frankenstein monster's revival is not described in the work. It is possible that when creating his "brainchild", Frankenstein used artificial materials and mechanical parts. M. Shelley's fantastic novel became a trendsetter of the plotline of horror films in the twentieth and twenty-first centuries (Dyakonova, 2005, pp. 5-17).

A new page in the development of robotics was opened by the invention of Pafnuti Lvovich Chebyshev. His famous "stop walk" became the world's first walking mechanism, which enjoyed great success at the World Exhibition in Paris in 1878. Subsequently, all developments in the field of walking robotics relied on this invention of the Russian scientist (Walking Machine, n.d.).

In modern history, for the first time, the word "robot" was used by the Czech writer Karel Čapek in his popular science play "Rossum Universal Robots" in 1920. The word "robot" comes from the Czech word "robota", meaning hard physical labour. The play takes place in the near future, where robots were created and sold to do hard work. Over time, robots have acquired the ability to think, make independent decisions, and realize their mental and physical superiority over humans. Subsequently, having declared war on the entire human race, the robots defeated and destroyed all life on the planet (Čapek, n.d.).

Isaac Asimov, in his novel "Round Dance" published in 1942, proposed the word robotics for use and formulated the so-called laws of robotics, which have become immutable for many writers (Azimov, 2005).

\section{Starting the Epoch of \\ Artificial Intelligence}

Since the 40 s of the last century, the creation of robotic manipulators, the first industrial and personal computers, is developing rapidly. These are the British decryption machine "Colossus", and the industrial manipulator "Unimate", and the programmable robot "Mister Televox", and the robot "Electro" with its robotic dog "Sparko", etc. ("Humanoid Robots", 2021).

Thus, we see that the idea of creating animated artificial mechanisms is characteristic of all eras, starting from ancient times. Moreover, in the XXI century, it becomes especially relevant in connection with the development of a "mechanism" with a valid algorithm for making a problem solution that is not provided for by the program. It is about the concept of "artificial intelligence".

So, the concept of "artificial intelligence" from mythology, legends, fiction, both unscientific and scientific, migrated into philosophy and purely scientific knowledge. Under the prevailing conditions of the influence of machine technology on human life, it really worries many people, including researchers of these problems, particularly in the aspect of the unpredictability of the choice of the algorithm of action in a given situation. 
Under "artificial intelligence" is primarily meant "a metaphorical concept to designate a system of human-created means that reproduce certain functions of human thinking". The very concept of "artificial intelligence" is interpreted in different ways in the literature. However, two main meanings of this concept can still be distinguished: 1) an urgent, most important interdisciplinary, comprehensive study of the artificial intelligence' phenomenon; 2) modelling and imitation of human intelligence, its psychic and mental processes in a computer, as well as the creation of an "electronic brain", a technical device that, in principle, will surpass human intelligence. In the literature, the following characteristic features of the "artificial intelligence" are usually called (Oreshnikov \& Shkerina, 2017, pp. 5-11):

- the ability to solve complex problems, store large amounts of information and work with them;

- the presence in them of their own internal model of the external world; this model provides individuality, the relative independence of the system in assessing the situation, the possibility of semantic and pragmatic interpretation of requests to the system;

- the ability to replenish existing knowledge;

- the ability to deduce that is, to generate information that is not explicitly contained in the system; this quality allows the system to construct an information structure with new semantics and practical orientation;

- the ability to operate in situations related to various aspects of fuzziness, including "understanding" of natural language;

- the ability to interact with a person in a dialogue;

- the ability to adapt (Oreshnikov \& Shkerina, 2017, pp. 5-11).
It would be natural to assume that the creation of the science of artificial intelligence will become an urgent problem. However, here, too, the first thoughts on this matter already belonged to the era of modern times.

The very possibility of thinking about the concept of "artificial intelligence" was greatly influenced by the birth of mechanistic materialism, which begins with the work of the already mentioned great Frenchman R. Descartes "Discourse on the Method" (1637) and immediately after that the work of T. Hobbes "Human nature" (1640). Descartes suggested that the animal is a kind of complex mechanism, thereby formulating a mechanistic theory.

Furthermore, it is important to understand how exactly mechanistic materialism differs from ancient materialism, whose views are captured in the works of Aristotle, and the subsequent dialectics of Hegel, dialectical and historical materialism in the person of L. Feuerbach, K. Marx, F. Engels, V. Lenin... The fact is that mechanistic materialism is aimed at the mechanistic origin of organisms, while ancient materialism is aimed at the mechanistic origin of nature, and dialectical and historical materialism refers to the manifestations of the mechanism in society.

Therefore, it is clear that without understanding the mechanism in organisms, there could be no talk of understanding artificial intelligence even in the most primitive sense, and the presence of the mechanistic nature of nature and society goes beyond the scope of artificial intelligence, and, strictly speaking, are not necessary prerequisites.

It is also interesting to note the technological prerequisites for the emergence of the science of artificial intelligence. So, in $1623 \mathrm{~W}$. Shikard built the first mechanical digital computing machine, which was followed by the machines of B. 
Pascal (1643) and G. Leibniz (1671). Leibniz was also the first to describe the modern binary number system, although many great scientists periodically became interested in this system. Also, the outstanding German mathematician and philosopher describes the following thought experiment in "Monadology". He suggests imagining a machine the size of a mill ("Leibniz's mill") that simulates feelings, thoughts and perceptions. Furthermore, if one goes inside such a machine, then none of the moving parts that ensure its operation will be consciousness or an explanation of perception. Therefore, Leibniz tried to show that physical states alone are not enough for the functioning of consciousness (Cole, 2015).

In Russia, some research has also been carried out in the field of studying the possibility of some manifestations of artificial intelligence. In 1832, the collegiate adviser S. N. Korsakov put forward the principle of developing scientific methods and devices to enhance the capabilities of the mind and proposed a series of "intelligent machines", in the design of which, for the first time in the history of informatics, he used perforated cards (Mikhailov, n.d.). In the $19^{\text {th }}$ century, C. Babbage and A. Lovelace worked on a programmable mechanical computer (Padua, 2008).

The actual birth of the science of artificial intelligence falls at the beginning of the $20^{\text {th }}$ century. In 1910-1913, B. Russell and A. N. Whitehead published Principles of Mathematics, which revolutionized formal logic. In $1941 \mathrm{~K}$. Zuse built the first working software-controlled computer. Later, W. McCulloch and W. Pitts, in 1943, published the work "Logical calculus of ideas inherent in nervous activity", which laid the foundations of neural networks. They proposed the concept of an "artificial neural network". D. Hebb, in his work "Organization of behavior" (1949), described the basic principles of training neurons. Several years later, these ideas were developed by the American neurophysiologist F. Rosenblatt. He proposed a diagram of a device that can simulate the process of human perception and called it "perceptron" (Averkin, Gaaze-Rapoport, \& Pospelov, 1992).

In 1976, the American scientists A. Newell and $\mathrm{H}$. Simon proposed a hypothesis about the physical symbol system, also called the "Newell and Simon hypothesis". The meaning of this hypothesis is that "a physical symbol system has the necessary and sufficient means to perform basic intellectual operations" (Russell \& Norvig, 2007). By intelligent operations, in this case, we mean the actions of strong artificial intelligence. Thus, without symbolic calculations, it is impossible to perform meaningful actions, and the ability to perform symbolic calculations is quite sufficient to become able to perform meaningful actions (Russell \& Norvig, 2007).

The Soviet Union did not lag in this race to build intelligent machines. Among Soviet scientists, artificial intelligence was the main field of scientific activity of D. A. Pospelov. Here D. A. Pospelov's scientific interests are connected with modelling human behaviour, formalizing reasoning, general problems of modelling life processes in natural and artificial systems. In particular, he was the first in the world to develop an approach to decision-making based on semiotic models, which served as a theoretical basis for situational management of large systems (Averkin, GaazeRapoport, \& Pospelov, 1992).

\section{Philosophical Problems of Artificial Intelligence}

And what about the philosophers? In fact, they stay away from the problems of artificial 
intelligence? Philosophy immediately critically interpreted all these new theoretical developments. The philosophy of artificial intelligence, created on the head of the day, asks questions about the "thinking of machines", and these questions reflect the interests of various researchers of artificial intelligence, philosophers, researchers of cognitive (cognitive) activity. The answers to these questions depend on what one means by saying "intelligence" or "consciousness" and which "machines" are the subject of discussion.

The most striking discussions in the philosophy of artificial intelligence are the question of the possibility of machine thinking. The question "Can a machine think?", which led researchers to create a science of modelling the human mind, was posed by A. Turing in 1950. The two primary and most recurrent points of view on this question are strong and weak artificial intelligence hypotheses.

John Searle introduced the term "strong artificial intelligence", and his approach is characterized by: "Moreover, such a program will not be just a model of the mind; in the literal sense of the word, it will itself be a mind, in the same sense in which the human mind is a mind" (Artificial Intelligence, 1990).

In contrast to this approach, supporters of the hypothesis of weak artificial intelligence prefer to consider programs only as a tool that allows solving specific problems that do not require the full spectrum of human cognitive abilities.

In his thought experiment called The China Room, John Searle shows that even passing the famous Turing test may not be a sufficient criterion for a machine to have an actual thought process. Hence, it follows that thinking is a process of processing information stored in memory: analysis, synthesis and self-study. The American scientist R. Penrose (1989) took precisely the same position, who in his book "The Emperor's New Mind" argues the impossibility of the emergence of the process of thinking based on formal systems.

So, the theory of strong artificial intelligence suggests that computers can acquire the ability to think and be aware of themselves as a separate person (in particular, to understand their thoughts), although their thinking process should not necessarily be similar to the human one. Weak artificial intelligence theory rejects this possibility (Luger \& Stubblefield, 2004).

In the philosophical literature, regarding the reasoning about the concept of "artificial intelligence", friendly artificial intelligence is often mentioned. It is defined as a hypothetical type of artificial intelligence that does not negatively affect humans. Many concepts of Friendly Artificial Intelligence assume that it will be harmless for humans and provide material and information support to satisfy each individual's desires and needs fully. "Friendly" in this context is a technical term, which does not mean that artificial intelligence will necessarily experience feelings of attachment and closeness to humanity (Yudkowsky, 2007).

To finally determine the capabilities of artificial intelligence, it is necessary to define the concept of "intelligence" directly in philosophy. There are different points of view on this issue. The analytical approach involves the analysis of the higher nervous activity of a person to the lowest, indivisible level (the function of higher nervous activity, an elementary reaction to external stimuli, irritation of the synapses of a set of neurons connected by function) and the subsequent reproduction of these functions. There is a definition of intelligence as the ability to solve 
intellectual problems. Here, an intellectual task is understood as a task for which there is no known solution algorithm. That is a task for which one needs to create an algorithm from scratch, for example, the proof of an unproven theorem, a scientific discovery, artistic activity, etc.

Finally, a logical step in the development of philosophical thinking about artificial intelligence was the introduction of this concept into a particular philosophical science - epistemology the science of reliable knowledge within the framework of philosophy. Philosophers dealing with this issue solve questions similar to those that are solved by artificial intelligence engineers about how to represent best and use knowledge and information (Petrunin, Ryazanov, \& Savelyev, 2010).

The most challenging problems in the framework of a philosophical study of the problems of artificial intelligence is ethical. A number of ethical questions are proposed by modern philosophers for the developers of machines with a free-action algorithm. These include: if in the future machines can reason, be aware of themselves and have feelings, then what makes a person a person, and a machine a machine?; if in the future machines can be aware of themselves and have feelings, will it be possible to exploit them, or will they have to be empowered?; if machines can reason in the future, how will the relationship between humans and machines develop? This issue has been considered more than once in works of art using the example of the confrontation between people and machines.

It should be noted. However, that man is not just a conscious being, but also an unconscious; not just rational, but also irrational. The formation of the human "Me" takes place over a long time by forming a personality in it through experience and cognition. It should be said that only a person is able to "exist", to reflect, to separate himself from the environment. Lacking biological specialization (Andryushina, 2014, pp. 103105), he perceives reality in all its diversity and contradictions. Man himself is a "purely dialectical" being, but besides the fact that he, in comparison with other biological species, being an "insufficient being", is also a "spiritual being", because he has not just some kind of set of moral values and attitudes, opinions and judgments, but such an ambiguous phenomenon as faith lives in it. Only a person seeks to know the truth of his being and can view it through the prism of a transcendental and not always explainable by means of rational comprehension. Therefore, we can ask the question: will artificial intelligence, in the course of its improvement, ever comprehend spirituality like a person? Will he be able not only to realize himself as a person and at the same time, exist like a person? (Andryushina, 2014, pp. 103-105).

Here it is necessary to note the other side of the issue. Man, as the creator of the artificial environment - culture, is the creator of the most important means of communication - language, through which he seeks to express his thoughts, feelings and experiences. However, it also contributes to the alienation of a person, for the poverty of language does not allow expressing the entire volume of the actual experiences of individuals. In the modern Internet space, where the capabilities of artificial intelligence are actively used, information systems carry out complex analysis and processing of the linguistic data entered by the user. They are trying to find the most optimal options for answering a request, establishing a correlation between the requested and available information, but mechanics, even being improved, cannot still go beyond mechanics, because for it, language is alienation as well (An- 
dryushina, 2014, pp. 103-105).

\section{Conclusion}

Thus, the philosophical problems in the study of artificial intelligence not only do not have a strictly outlined circle of research but are continually expanding, along with the expansion of knowledge about artificial intelligence. The historically established knowledge of people about artificial mechanisms capable of replacing a person in a particular activity turned into the ability to create something new, hitherto unprecedented - animate inanimate matter. In the future, all this knowledge was dressed in the armour of scientific theories, the result of which was the creation of a theory of "artificial intelligence". What can we expect from the full-scale development of cyberspace? Attacks by "clones", terminators, or all the same friendly relations between thinking machines and humanity, no matter how paradoxical it may sound. The answer to this question, apparently, is already in the near future.

\section{References}

Andryushina, L. V. (2014). Chelovek kak kul'turnoye zhivotnoye $v$ nemetskoy antropologii nachala XX veka (Man as a Cultural Animal in German Anthropology of the Early $20^{\text {th }}$ Century, in Russian). Scientific notes of the Oryol State University. Series: Humanities and Social Sciences, 5, 103-105.

Averintsev, S. S. (2007). Golem (Golem, in Russian). In Great Russian Encyclopedia. Retrieved from http://bre.mkrf.ru/religious_studies/text/2366594.

Averkin, A. N., Gaaze-Rapoport, M. G., \& Pospelov, D. A. (Eds.) (1992). Tolkovyi slovar' po iskusstvennomu intellektu (Explanatory Dictionary of Artificial Intelligence, in Russian). Moscow: Radio and Communication.

Azimov, A. (2005) Khorovod (Round Dance, in Russian). Moscow: Eksmo. Retrieved from https://www.litmir.me/br/?b=21$96 \& p=1$.

Čapek, K. (n.d.). RUR (RUR, in Russian). Retrieved December 12, 2020 from: http://www.lib.ru/SOCFANT/CHAPE $\underline{\mathrm{K} / \text { rur.txt. }}$

Cave, S., \& Dihal, K. (2019). Hopes and Fears for Intelligent Machines in Fiction and Reality. Nature Machine Intelligence Journal, 1(2), 74-78.

Chelovekopodobnyye roboty: pol'za i problemy antropomorfnykh mekhanizmov (Humanoid Robots: The Benefits and Problems of Anthropomorphic Mechanisms, in Russian). (n.d.). Retrieved January 1, 2021 from: https://habr.com/ru/company/toshibarus/blog/435536/.

Chistyakov, M. B. (1871). Narodnoe predanie o Bryuse (Iz vospominaniy moyego tovarishcha) (Folk Legend about Bruce (From the Memoirs of My Friend), in Russian). Russian Starina, 4(8), 167170.

Cole, D. (2015). The Chinese Room Argument. In Stanford Encyclopedia of Philosophy. Retrieved January 1, 2021 from: https://plato.stanford.edu/entries/chines e-room/.

Diogenes Laertius (1986). O zhizni, ucheniyakh $i$ izrecheniyakh znamenitykh filosofov (On Life, Teachings and Sayings of Famous Philosophers, in Russian). (A. F. Losev, Trans). Moscow: Mysl'.

Dyakonova, N. Y. (2005). Angliyskaya proza 
epokhi romantizma (English Prose of the Era of Romanticism). In Shelli, $M$. Frankenshteyn, ili Sovremennyy Prometey (Frankenstein, or Modern Prometheus, in Russian) (pp. 5-17). (Z. Alexandrov, Trans.). Saint-Petersburg: Azbuka-classic.

Gehlen, A. (1988). O sistematike antropologii (On the Taxonomy of Anthropology, in Russian). Moscow: Progress.

Iskusstvennyi intelekt: razlichnye vzglyady na problem (Artificial Intelligence: Different views on the Problem, in Russian). (1990). Scientific American, 3. Retrieved December 13, 2020 from: http://www.raai.org/library/books/sirl/ai .htm.

Jones, D. (1985). Izobretenie Dedala (The Invention of Daedalus, in Russian). Moscow: MIR.

Lektorsky, V. A. (2015). Vozmojny li nauki o cheloveke? (Are Human Sciences Possible? in Russian). Questions of Philosophy Journal, 5, 3-15.

Losev, A.F. (1991). Gefest (Hephaestus, in Russian). In Myths of the Peoples of the World, Chapter 1 (pp. 299-300). Moscow: Sovetskaya entsiklopediya.

Luger, G., \& Stubblefield, W. (2004). Artificial Intelligence: Structures and Strategies for Complex Problem Solving. ( $5^{\text {th }}$ ed.). San Francisco: The Benjamin-Cummings Publishing Company.

Mikhailov, A. S. (n.d.). Izobreteniya A. N. Korsakova (Inventions of A. N. Korsakov, in Russian). Retrieved December 13, from: http://www.ict.nsc.ru/jspui/bitstream/ICT/913/1/kosakov.pdf.

Oreshnikov, I. M., \& Shkerina, T. I. (2017). Filosofskiye razmyshleniya o probleme is- kusstvennogo intellekta (Philosophical Reflections on the Problem of Artificial Intelligence, in Russian). Philosophy of Education, 4, 5-11.

Padua, S. (2008). Neveroyatnye priklyucheniya Lavleys i Bebbidzha. (Pochti) pravdivaya istoriya pervogo komp'yutera (The Incredible Adventures of Lovelace and Babbage. (Almost) True Story of the First Computer, in Russian). Moscow: Mann, Ivanov and Ferber.

Penrose, R. (1989). The Emperor's New Mind: Concerning Computers, Minds and The Laws of Physics. Oxford University Press.

Petrunin, Y. Y., Ryazanov, M. A., \& Savelyev, A. V. (2010). Filosofiya iskusstvennogo intellekta $v$ kontseptsiyakh neyronauk (Philosophy of Artificial Intelligence in the Concepts of Neurosciences, in Russian). ( $1^{\text {st }}$ ed). Moscow: MAKS Press Publ.

Russell, S., \& Norvig, P. (2007). Iskusstvennyi intellekt: sovremennyi podkhod (AIMA) = Artificial Intelligence: A Modern Approach (AIMA) (Artificial Intelligence: A Modern Approach $($ AIMA) $=$ Artificial Intelligence: A Modern Approach (AMA), in Russian). ( $2^{\text {nd }}$ ed). Moscow: Williams.

Russo, L. (2004). The Forgotten Revolution: How Science Was Born in 300 BC and Why it Had to Be Reborn. Berlin: Springer.

Shank, K. (2007). Filon Aleksandriyskiy. Vvedeniye $v$ zhizn' $i$ tvorchestvo (Philon of Alexandria. Introduction to Life and Work, in Russian). Moscow: BBI.

Stopokhodyashchaya mashina (Walking Machine, in Russian). (n.d.). Retrieved De- 
cember 13, 2020 from: https://etudes.ru/etudes/tchebyshev-plantigrade-machine.

Sweeney, B. J. (2007). Leonardo's Hands Picture and Video Galleries. Retrieved December 12, 2020 from: http://www.leonardoshands.com/artman2/publish/leonardo-picture-and-video-galleries/Pictures of Leonardo da_Vinci_s_Lost Robot Knight.

The Amazing Story of Jaquet Droz (n.d.). Retrieved December 12, 2020 from: https://www.jaquet-droz.com / ru / theextraordinary-history-jaquet-droz.

The Claw. (1999). Retrieved December 12, 2020 from: https://web.archive.org/web/201- 61125180916/http://www.bbcactivevid eoforlearning.com/1/TitleDetails.aspx?TitleID $=23405$.

Wood, G. (2002). From “Edison's Eve: A Magical History of the Quest for Mechanical Life". New York: Anchor Books.

Yezhov, V. V. (2004). Mify Drevnego Kitaya (Myths of Ancient China, in Russian). Saint Petersburg: AST.

Yudkowsky, E. (2007). Iskusstvennyi intellekt kak pozitivnyi i negativnyi faktor global'nogo riska (Artificial Intelligence as a Positive and Negative Factor in Global Risk, in Russian). Retrieved January 29, 2021 from: https://ru.scribd.com/doc/13574249/. 